\title{
Chemical and Physiological Changes During the Embryonic Development of the Spider Crab, Hyas araneus L. (Decapoda: Majidae)
}

\author{
Sven Petersen ${ }^{1}$ and Klaus Anger ${ }^{2}$ \\ ${ }^{1}$ Universität Rostock, Fachbereich Biologie, Freiligrathstr. 7/8, D-18051 Rostock, Germany and \\ ${ }^{2}$ Biologische Anstalt Helgoland, Meeresstation, D-27498 Helgoland, Germany
}

\begin{abstract}
During embryogenesis of the spider crab, Hyas araneus, four developmental phases were distinguished microscopically: cleavage, gastrula, embryo differentiation, prehatching phase. Changes in fresh weight $(F W)$, dry weight $(\mathrm{DW})$, ash-free dry weight $(\mathrm{AFDW})$, water, carbon $(\mathrm{C})$, nitrogen $(\mathrm{N})$, total lipids, proteins, carbohydrates, and respiration rates were measured in developing eggs. The percentage of water increased from $52 \%$ to $87 \%$ of $\mathrm{FW}$, most rapidly after the beginning of organ differentiation and during hatching. The accumulation of minerals followed a similar pattern, with ash increasing from $3 \%$ to $7 \%$ of DW in the eggs, and to $26 \%$ at hatching. Inverse (decreasing) patterns were observed in organic matter (AFDW, C, N, lipids, proteins). During development from the undivided egg to the freshly hatched zoea larva, $69 \%$ of the initial lipid and 35\% of protein were depleted. Carbohydrates represented a minor constituent of yolk ( $1 \%$ to $2 \%$ of DW). In spite of a decreasing protein content, $\mathrm{N}$ remained almost constant. This suggests a final increase in low-molecular nitrogenous substances, which are not quantitatively detected by the Lowry method (probably free amino acids); we suspect that these may play a role in the hatching process. In the gastrula, and from about 3 months after the onset of organ differentiation until 1 or 2 months before hatching, low embryonic respiration rates as well as microscopical observations indicated the existence of developmental resting periods. Such diapause-like intervals may coordinate the time of hatching with a short season of planktonic food production in high latitudes. The relative importance of lipids and proteins as fuel for embryogenesis is compared with that in other crustacean taxa. сомр віоснем pнysiol 117B;2:299-306, 1997. (C) 1997 Elsevier Science Inc.
\end{abstract}

KEY WORDS. Brachyura, embryogenesis, lipid degradation, protein degradation, carbon, nitrogen, embryo respiration, developmental resting period

\section{INTRODUCTION}

Biochemical and physiological aspects of larval and early juvenile development have been investigated in great detail in the northern spider crab, Hyas araneus, so that this species has become a "standard model system" for such studies $[(3,4)$ and earlier papers cited therein]. Nothing, however, has been known about similar aspects of its embryogenesis. This is also in contrast to several other decapod crustacean species, where chemical and physiological changes have been studied in detail during the course of embryogenesis [e.g., $(12,23,7)]$.

The present study describes changes in chemical and physiological parameters during the course of embryonic development in $H$. araneus: contents of carbon, nitrogen, lipid, protein, carbohydrate, ash, water, respiration rate. A comparison of these aspects of embryogenesis with those in

Address reprint requests to: S. Petersen, Universität Rostock, Fachbereich Biologie, Freiligrathstr. 7/8, D-18051 Rostock, Germany, Tel. 0381-4982024; Fax 0381-498-2011; E-mail: nfd522@cksl.rz.uni-rostock.de Received 12 June 1996; accepted 18 December 1996. other decapod crustacean species has become particularly interesting, since the duration of egg development was recently shown to be unusually long in $H$. araneus. There is evidence that the total time span between spawning of eggs and hatching of larvae is approximately 2 years (25), whereas embryonic development in other European brachyuran species has never been reported to last longer than 1 year [review:(6)].

\section{MATERIALS AND METHODS}

Ovigerous females of $H$. araneus were dredged during October 1992 from c. 30-50 m depth near Helgoland (German Bight, North Sea). They were maintained in flow-through aquaria at temperatures that approximately followed the ambient surface sea water temperature near Helgoland (25).

The crabs were fed with mussel (Mytilus edulis) meat every 4 to 6 days. Every 2 to 4 weeks, eggs were taken from the abdominal appendages for chemical analyses, respiration measurements, and microscopical determination of the developmental stage. During each of the three studied pe- 


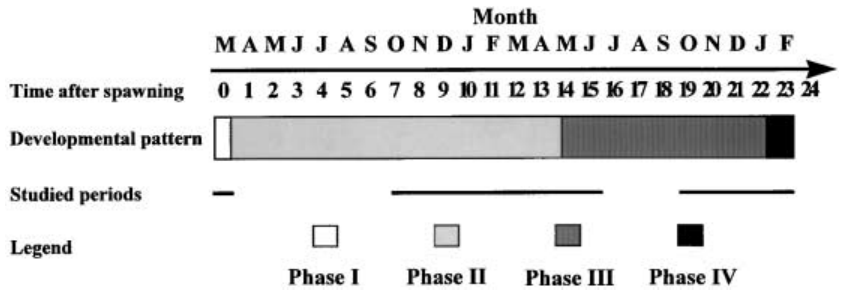

FIG. 1. Course of embryonic development in $\boldsymbol{H}$. araneus (after 25). Samples for chemical analyses were taken during the observation periods indicated. Phase $I=$ cleavage, Phase II = gastrula, Phase III = organ differentiation, Phase IV = pre-hatching.

riods (Fig. 1), the replicate egg samples were taken from the same female.

For the measurement of water content, 10 to 20 eggs were briefly rinsed with deionized water, blotted on filter paper, put into preweighed silver cartridges, and their fresh weight (FW) was determined immediately on a Mettler UM 3 microbalance to the nearest $0.1 \mu \mathrm{g}$. After freeze-drying to constant weight, dry weight (DW) was measured, and the water content calculated as difference between FW and DW. For determination of the ash content, the same samples were ashed in a muffle oven at $500^{\circ} \mathrm{C}$ for $5 \mathrm{hr}$, and weighed again.

Five parallel samples (with six eggs per cartridge) were taken for determinations of carbon $(\mathrm{C})$ and nitrogen $(\mathrm{N})$ contents. They were also rinsed with deionized water, freeze-dried, weighed, and eventually analyzed in a Carlo Erba Science Model $1106 \mathrm{CHN}$ analyzer [for more details, see $(3,4)]$.

Total lipids (22 eggs per analysis; homogenized in conc. $\mathrm{H}_{2} \mathrm{SO}_{4}$ for $10 \mathrm{~min}$ at $100^{\circ} \mathrm{C}$ ) were measured photometrically with a Merckotest reagent kit (Merck, Darmstadt), utilizing the sulfophosphovanillin reaction (38). Proteins were determined photometrically with the folin phenol reagent (20), after homogenization of seven eggs per analysis in deionized water, precipitation of the proteins with TCA, separation of the precipitate by centrifugation, and resolubilization in $1 \mathrm{~N} \mathrm{NaOH}$. The supernatant from the protein determination was used to measure the carbohydrate content of the eggs. Polymers were hydrolized with $6 \mathrm{~N} \mathrm{HCl}$ $\left(250 \mu \mathrm{l} / 400 \mu \mathrm{l}\right.$ supernatant) at $65^{\circ} \mathrm{C}$. After neutralization with $6 \mathrm{~N} \mathrm{NaOH}$, the sum of free glucose and glycogen in the sample was quantified using the Glucose-(Hexokinase)Kit (Sigma Chemical Co., St Louis, MO, 16-UV). Determinations of water, DW, C, and N comprised five replicates each, those of ash and biochemical constituents (protein, lipid, carbohydrates), three replicates. Respiration rates were measured in closed bottles $(c .60 \mathrm{ml})$ using the Winkler technique (13), with five replicate determinations with 100 eggs or 10 larvae, respectively, each and four replicate blanks (without animals). The incubation time was 18-45 $\mathrm{hr}$ to obtain differences in oxygen content between blanks and samples of about 10\% (3).
All average values are given as arithmetic mean $(\overline{\mathrm{x}}) \pm$ standard deviation (SD). Student's $t$-test was used to test for significant $(P<0.05)$ differences in chemical composition at different times of development. The data of weightspecific respiration rate were subject to analysis of variance (ANOVA) and pairwise Tukey's Test (18). The statistical analyses were made with the aid of SYSTAT for Windows, Version 5.03

Embryogenesis was studied microscopically and divided into four developmental phases. An approximate time scale (25) is shown in Fig. 1.

I. Cleavage: Cell-borders become visible in the amorphous yolk. The colour of the eggs is orange.

II. Gastrula: A small, transparent, yolk-free area becomes visible inside the eggs. No distinct changes in cell-number and cell-size occur. The eggs are still orange.

III. Differentiation: Eye-pigment, heart-beat, appendages, and increasing pigmentation become visible. The colour of the eggs turns brown.

IV. Pre-hatching phase: The dark and now relatively small yolk-filled area in the eggs divides into two separate parts. The embryos begin to move inside the eggs.

\section{RESULTS}

During the course of development from the undivided egg to a freshly hatched larva, the most pronounced changes of chemical composition were observed in the contents of water, ash, carbon, and lipids, while the fractions of nitrogen, proteins, and carbohydrates varied to lesser extents. Protein was consistently the predominant fraction of yolk (varying between $33 \%$ and $40 \%$ of egg DW), followed by lipids (20\% to $31 \%)$. Immediately after hatching, the amounts of organic constituents within the DW of larvae were significantly $(P<0.05)$ lower than in the eggs shortly before the hatching event. Their DW contained only $22 \%$ protein, $9.4 \%$ lipid, and $1.6 \%$ carbohydrates. The effect of yolk utilization on DW was partially compensated by the uptake of minerals (increasing ash content), so that DW changed only little during major parts of the embryonic development (Fig. 2): DW in Phase II eggs was not significantly different from DW in Phase IV eggs $(P>0.05)$. During the hatching process, however, a dramatic uptake of water and minerals caused a sudden increase in both FW and DW (from 222 to $536 \mu \mathrm{g}$, and from 60.5 to $69.5 \mu \mathrm{g}$, respectively).

The average initial water content was in undivided eggs $76 \mu \mathrm{g}$ (or $52 \%$ of $\mathrm{FW}$ ). It increased gradually during embryonic development, to $162 \mu \mathrm{g}$ (or $73 \%$ of FW), and dramatically during hatching, to $466 \mu \mathrm{g}$ (87\% of FW; Fig. 3a). From egg-laying to hatching, this means an uptake of c. $390 \mu \mathrm{g}$, or a six-fold increase, of water per individual. The highest rates of increase occurred at the beginning of Phase III, during the last two months of embryogenesis, and during the hatching event (Fig. 3a). 


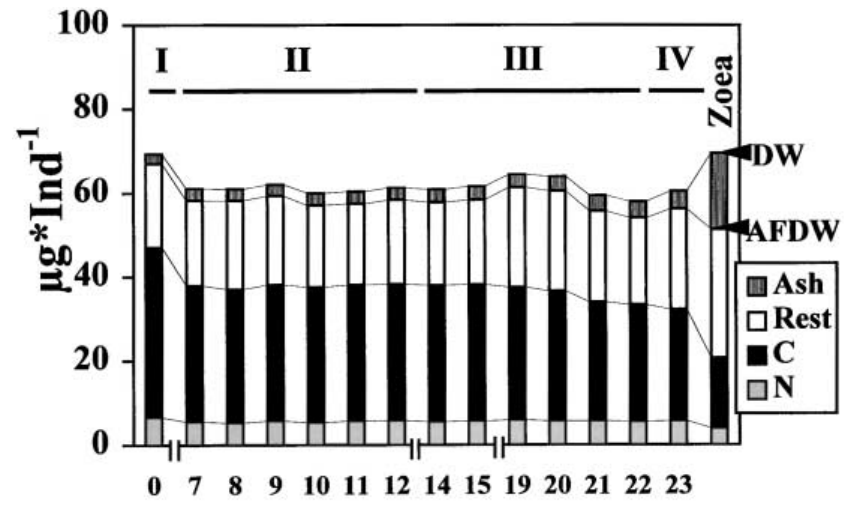

Time after spawning (months)

FIG. 2. Changes during embryonic development of $\boldsymbol{H}$. araneus in: dry weight (DW), ash-free dry weight (AFDW; $n=$ $3)$, ash $(n=3)$, carbon $(C ; n=5)$, nitrogen $(N ; n=5)$, undetermined matter (rest). $\overline{\mathbf{x}}$; developmental phases I to IV: see Fig. 1.

Also in the ash content, the most extreme changes occurred during hatching (Fig. 3b). In undivided eggs, $2.3 \mu \mathrm{g}$ minerals (or $3.3 \%$ of DW) were measured. The inorganic fraction doubled during the course of embryogenesis to 4.3 $\mu \mathrm{g}$ in Phase IV (7.1\% of DW). In freshly hatched larvae, it reached $18.2 \mu \mathrm{g}(26 \%$ of DW). Hence, almost seven times more minerals were taken up shortly before and during hatching than during 2 years of embryonic development.
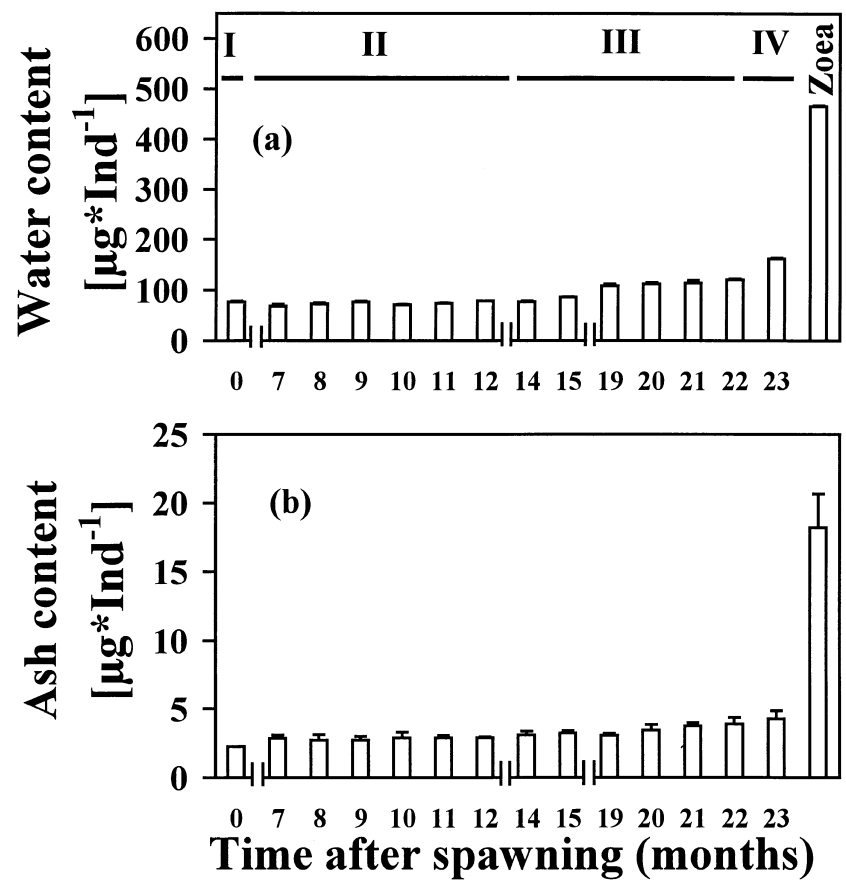

FIG. 3. Changes during embryonic development of $\boldsymbol{H}$. araneus in: (a) contents of water $(n=5),(b)$ of ash $(n=3) ; \bar{x}$ \pm SD; developmental phases I to IV: see Fig. 1.
As a consequence of slightly decreasing total DW and a concomitant significant $(P<0.05)$ increase in the ash fraction (comparing Phase I vs Phase IV eggs), the amounts of total organic matter (ash-free dry weight, AFDW) decreased during embryonic development (Fig. 2).

As in water and ash, conspicuous changes were observed also in the proportions of carbon and nitrogen. The $\mathrm{C}$ content was significantly $(P<0.05)$ higher in undivided Phase I eggs than 7 months after spawning, during Phase II. Then, until the end of Phase II, the C content remained relatively constant. It decreased significantly $(P<0.05)$ again during developmental phases III and IV of egg development and, in particular, during the hatching process (Fig. 2). Approximately one-third $(35 \%)$ of the initial amounts of $\mathrm{C}$ were depleted during embryonic development, causing a decrease from $58 \%$ to $44 \%$ of DW. Freshly hatched larvae contained only $41 \%$ of the initially available amounts measured in early embryos.

The nitrogen content of the eggs changed only little, showing during embryogenesis a slight decrease in the absolute amounts (from 6.5 to $5.7 \mu \mathrm{g}$ per egg). Since also egg DW decreased slightly, the weight-specific $\mathrm{N}$ content remained practically constant, at c. $9.4 \%$ of DW. Significant losses $(P<0.05)$ of $\mathrm{N}$, however, occurred during the hatching process (decreasing to $3.9 \mu \mathrm{g}$ per freshly hatched larva, or $5.6 \%$ of DW; Fig. 2). Proportionally greater changes in the content of $\mathrm{C}$ as compared with those in $\mathrm{N}$ are reflected by a decreasing trend in the $\mathrm{C}: \mathrm{N}$ weight ratio: It decreased from 6.2 in freshly laid eggs to 4.6 in Phase IV eggs shortly before hatching, and to 4.3 in zoea larvae immediately after hatching.

Approximately two thirds (69\%) of the initial lipid content and about one third (35\%) of the initially available proteins were depleted during development from the undivided egg to the freshly hatched larva (Fig. 4). Lipid depletion was, in particular, during the early phase of embryonic

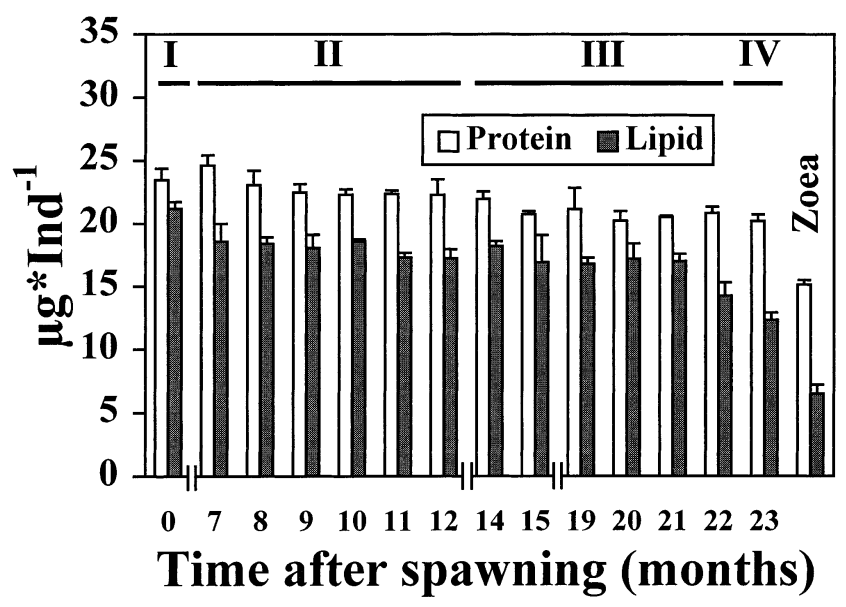

FIG. 4. Changes during embryonic development of $\boldsymbol{H}$. araneus in: contents of lipids $(n=3)$ and proteins $(n=3) ; \overline{\mathbf{x}}$ \pm SD; developmental phases I to IV: see Fig. 1 . 


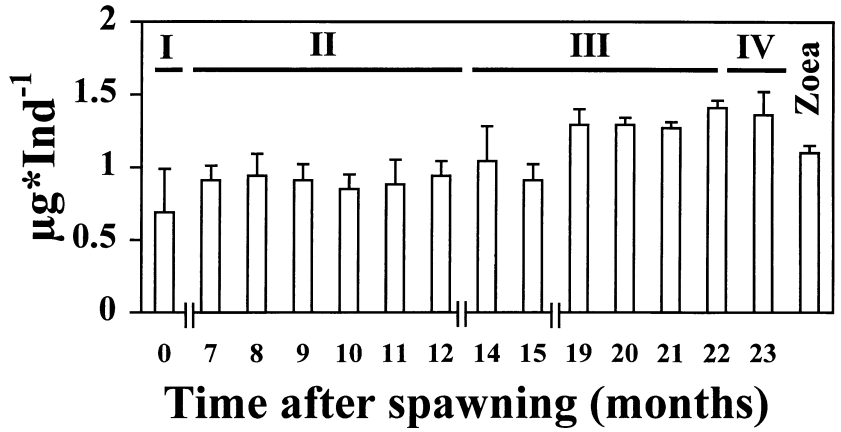

FIG. 5. Changes in the carbohydrate content during embry. onic development of $H$. araneus $(n=3) ; \overline{\mathbf{x}} \pm$ SD; developmental phases I to IV: see Fig. 1.

development, faster than that of protein. The lipid content of Phase II eggs, 7 months after spawning, was significantly lower $(P<0.05)$ than in freshly spawned Phase I eggs, whereas changes in the protein content during the same interval were not significant. Thereafter, until about 2 months before hatching, the amounts of both lipids and proteins decreased gradually, at similarly low rates. During long periods within Phase II and Phase III, changes in lipid and protein content were not significant. However, contents of lipid and protein were significantly different $(P<0.05)$, comparing Phase II eggs ( 7 months after spawning) and late Phase III eggs (21 months after spawning). During the last 2 months of embryonic development, the depletion of lipid exceeded proportionally again that of protein (Fig. 4): The lipid content decreased significantly $(P<0.05)$ during the last 2 months before hatching, whereas the change in protein content was not significant. The patterns of lipid and protein depletion are reflected by corresponding changes in the lipid:protein weight ratio: it was 0.9 in freshly laid eggs (Phase I), 0.833 months before hatching (late Phase III), 0.61 shortly before (Phase IV), and 0.4 immediately after hatching.

The carbohydrate fraction remained a minor constituent of yolk (Fig. 5). It increased significantly $(P<0.05)$ during embryonic development, doubling from about $0.7 \mu \mathrm{g}$ (or $1.0 \%$ of DW) in early eggs to $1.4 \mu \mathrm{g}(2.2 \%$ of DW) in late embryos. Apparently, the amounts of carbohydrates decreased significantly $(P<0.05)$ again, during hatching, to $1.1 \mu \mathrm{g}$ (1.6\% of DW; Fig. 5).

Degradation of biochemical constituents caused a significant decrease in the energy content of eggs. Freshly hatched larvae had less than one half of the initial energy content of early embryos (Fig. 6a). Since the average energy content of lipids is almost twice as high as that of proteins [39.5 vs $23.6 \mathrm{~J} / \mathrm{mg}$; (37)], these patterns show again that the lipid pool is the major fuel for embryonic development in $H$. araneus. This can be seen particularly clearly, when the remaining amounts of these two fractions are expressed as a percentage of total energy in eggs or larvae, respectively (Fig. 6b).

ANOVA indicated significant changes in weight-specific respiration rates during the embryonic development $(P<$
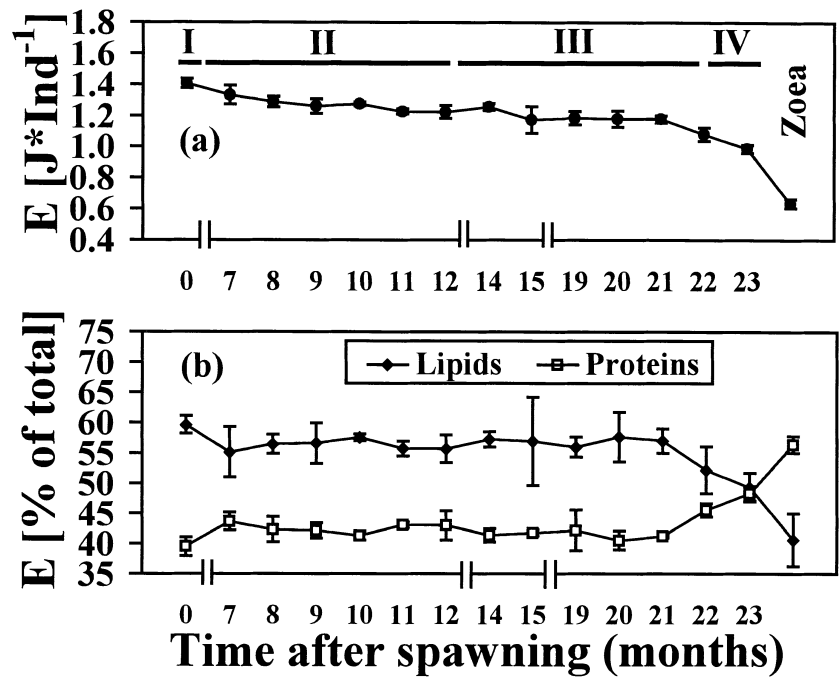

FIG. 6. Changes during embryonic development of $\boldsymbol{H}$. araneus in: (a) total energy content (calculated as sum of energy bound in major biochemical constituents: lipids, proteins, carbohydrates), and (b) the relative contributions of lipids and proteins, as a percentage of $(a) ; \overline{\mathbf{x}} \pm \operatorname{SD}(n=3)$; developmental phases I to IV: see Fig. 1.

0.05). The metabolically most active periods occurred during cleavage (Phase I; first 2 weeks after egg-laying), at the beginning of organ differentiation (early Phase III) and, in particular, shortly before and after the hatching process (Phase IV; Fig. 7). Between these periods, significantly lower respiration rates were observed (Table 1). Microscopical examination showed that the latter co-occurred with developmental resting periods in the gastrula (Phase II), and from about 3 months after the onset of organ differentiation until c. 1 or 2 months before hatching.

\section{DISCUSSION}

In contrast to the eggs of many terrestrial species, which only take up oxygen, those of aquatic invertebrates addi-

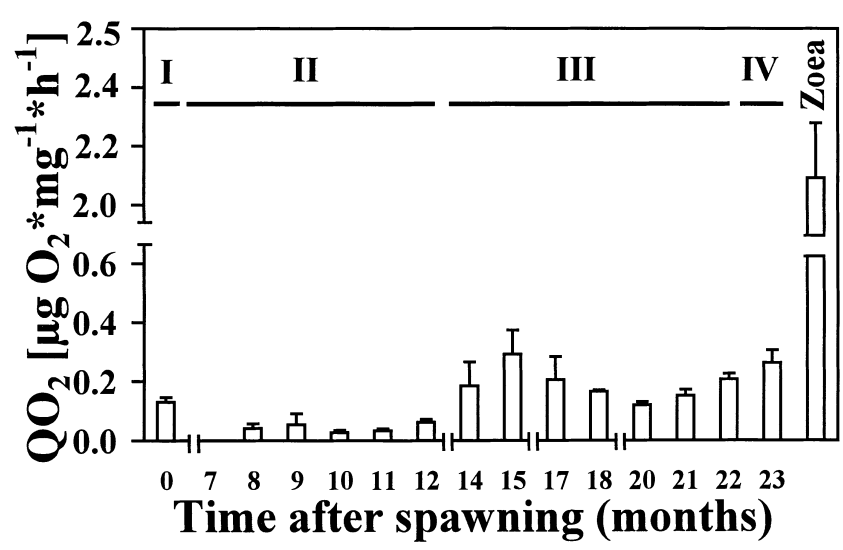

FIG. 7. Changes in the weight-specific respiration rate $\left(\mathrm{QO}_{2}\right)$ during embryonic development of $H$. araneus $(n=5), \overline{\mathbf{x}} \pm$ SD; developmental phases I to IV: see Fig. 1. 
TABLE 1. Respiration rates during the embryonic development of $\boldsymbol{H}$. araneus in $\boldsymbol{\mu g} \mathbf{O}_{2} * \mathbf{m g}^{-1} * \mathbf{h r}^{-1}\left(\mathbf{m e a n}^{\prime} \pm \mathrm{SD}, \boldsymbol{n}=\mathbf{5}\right)$ at different time (months) after spawning

\begin{tabular}{|c|c|c|c|c|c|c|c|c|c|c|c|c|c|c|c|c|c|}
\hline Time & Mean & SD & $\begin{array}{c}0 \\
0.13 \\
0.02\end{array}$ & $\begin{array}{c}8 \\
0.04 \\
0.02\end{array}$ & $\begin{array}{c}9 \\
0.05 \\
0.04\end{array}$ & $\begin{array}{c}10 \\
0.03 \\
0.01\end{array}$ & $\begin{array}{c}11 \\
0.03 \\
0.01\end{array}$ & $\begin{array}{c}12 \\
0.06 \\
0.01\end{array}$ & $\begin{array}{c}14 \\
0.18 \\
0.08\end{array}$ & $\begin{array}{c}15 \\
0.29 \\
0.08\end{array}$ & $\begin{array}{c}17 \\
0.21 \\
0.08\end{array}$ & $\begin{array}{c}18 \\
0.17 \\
0.01\end{array}$ & $\begin{array}{c}20 \\
0.12 \\
0.01\end{array}$ & $\begin{array}{c}21 \\
0.15 \\
0.02\end{array}$ & $\begin{array}{c}22 \\
0.21 \\
0.02\end{array}$ & $\begin{array}{c}23 \\
0.26 \\
0.04\end{array}$ & $\begin{array}{c}23 \text { (zoea) } \\
2.08 \\
0.19\end{array}$ \\
\hline 0 & 0.13 & 0.02 & & & & & & & & $*$ & & & & & & & $*$ \\
\hline 8 & 0.04 & 0.02 & & & & & & & * & $*$ & $*$ & & & & $*$ & $*$ & $*$ \\
\hline 9 & 0.05 & 0.04 & & & & & & & & $*$ & $*$ & & & & $*$ & $*$ & $*$ \\
\hline 10 & 0.03 & 0.01 & & & & & & & * & $*$ & $*$ & & & & $*$ & $*$ & $*$ \\
\hline 11 & 0.03 & 0.01 & & & & & & & * & $*$ & * & & & & * & $*$ & $*$ \\
\hline 12 & 0.06 & 0.01 & & & & & & & & $*$ & $*$ & & & & $*$ & * & * \\
\hline 14 & 0.18 & 0.08 & & * & & $*$ & * & & & & & & & & & & $*$ \\
\hline 15 & 0.29 & 0.08 & $*$ & $*$ & $*$ & $*$ & $*$ & * & & & & & * & & & & * \\
\hline 17 & 0.21 & 0.08 & & $*$ & $*$ & $*$ & $*$ & $*$ & & & & & & & & & $*$ \\
\hline 18 & 0.17 & 0.01 & & & & & & & & & & & & & & & $*$ \\
\hline 20 & 0.12 & 0.01 & & & & & & & & $*$ & & & & & & $*$ & $*$ \\
\hline 21 & 0.15 & 0.02 & & & & & & & & & & & & & & & $*$ \\
\hline 22 & 0.21 & 0.02 & & $*$ & $*$ & $*$ & * & * & & & & & & & & & * \\
\hline 23 & 0.26 & 0.04 & & * & $*$ & $*$ & * & * & & & & & $*$ & & & & $*$ \\
\hline 23 (zoea) & 2.08 & 0.19 & $*$ & $*$ & $*$ & * & $*$ & $*$ & * & * & * & * & $*$ & $*$ & $*$ & $*$ & \\
\hline
\end{tabular}

The stars indicate significant differences $(P<0.05)$ between respiration rates; Tukey's Test.

tionally absorb minerals and water during embryogenesis (21). Increasing rates of water uptake co-occurring with the onset of heart beat were found in several species of $\mathrm{Na}$ tantia, Anomura, and Brachyura (36). This was also the case in $H$. araneus, where an increasing water uptake was observed in late Phase III, during Phase IV, and at a maximum, during the hatching process. Also in the ash content, the most rapid increase occurred shortly before and during hatching. It is likely that this final influx of minerals and water facilitates the rupture of the egg membrane by means of increasing the internal pressure in the egg [for details of the hatching event see $(8,9,29,11)]$.

Decrease in specific weight is another consequence of water uptake. This effect does not play a role in demersal eggs, which are attached to the pleopods of the benthic mother animal, but it will increase the buoyancy of pelagic eggs and larvae. In early embryos of the antarctic krill (Euphausia superba), which has pelagic eggs, the initial water content is already as high as $80 \%$ of FW (26), but only $52 \%$ were measured in the demersal eggs of $H$. araneus. Consistently low values (ranging from $46 \%$ to $69 \%$ of $\mathrm{FW}$ ) were also measured in other marine crustaceans with demersal eggs $(10,22,23,24,31)$. In freshly hatched larvae of the same crustacean species, the water content ranged from $77 \%$ to $87 \%$ of FW (op. cit.). The buoyancy of pelagic eggs may be additionally increased by a high lipid content: while the eggs of $H$. araneus lose during their development a major part of their lipid fraction, those of krill show only little decrease (1).

Similarly, as already observed in a freshwater prawn, Macrobrachium rosenbergii ( 7 ), the developing eggs of $H$. araneus showed a significant decrease in the carbon content, while nitrogen remained practically constant. The latter is remarkable, as there was a concomitant decrease in the pro- tein content. This indicates an accumulation of other nitrogenous products, which are not quantitatively detected with the Lowry method (for instance free amino acids or, to some extent, ammonia). Those substances are osmotically active and hence, may enhance the water uptake in late embryos of $H$. araneus. A similar mechanism was described for Artemia embryos, which synthesize osmotically active glycerol immediately before hatching (12).

An accumulation of nitrogenous products other than proteins is suggested also by the relationship between $\mathrm{N}$ and protein. All protein values measured in the eggs of $H$. araneus were found below those predicted by the regression line which describes this relationship for the larval stages of the same species (Fig. 8b). However, the difference between predicted and measured values is small, and the present study provided relatively few parallel results of $\mathrm{N}$ and protein analyses which, in addition, were obtained only in a small range of values. Hence, the difference between the $\mathrm{N}$ :protein relationships in eggs and larvae, respectively, is statistically not significant. Further parallel measurements of elemental and biochemical composition of eggs, or a more detailed biochemical study (including amino acid composition), might reveal such differences.

The same is true for the relationship between $\mathrm{C}$ and total lipids in eggs and larvae of $H$. araneus. Lipid values measured in eggs were consistently above the regression line describing the C:lipid relationship in larvae of the same species (Fig. 8a). This is not surprising, as $\mathrm{C}$ is an integrator of all organic substances, including the fraction of proteins. Since the lipid:protein ratio is in the eggs on average higher than in the larval stages [cf. (3)], proportionally more $C$ is bound in the lipid fraction of the eggs as compared with that of larvae. 

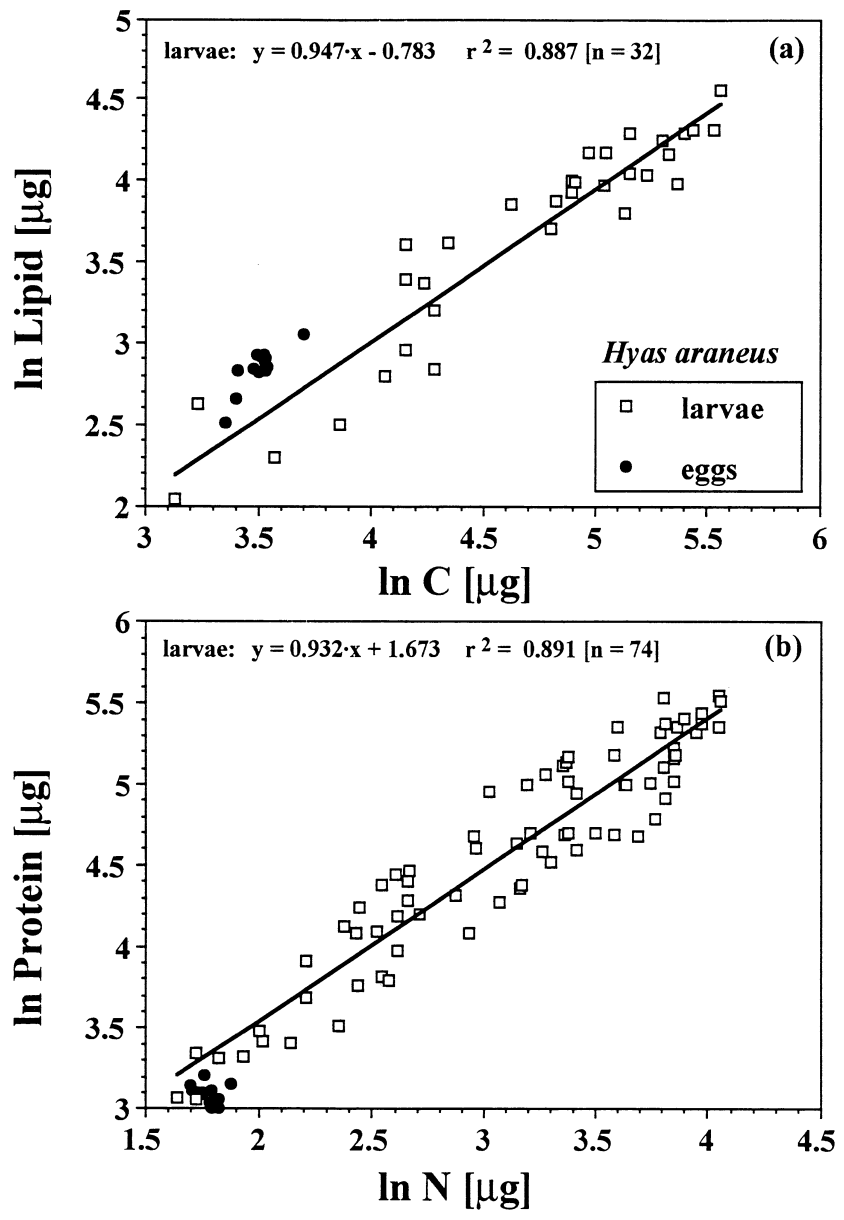

FIG. 8. Relationships between (a) carbon (C) and lipids, and (b) nitrogen (N) and proteins in eggs and larvae of $H$. araneus. Data for larvae from (3), and earlier papers cited therein; eggs: present study; all data logarithmically transformed. Regression equations only for larvae (not including egg data); $r^{2}=$ coefficient of determination, $n=$ number of data pairs from parallel analyses of identical materials.

Changes in the respiration rate during embryogenesis reflect variations in average metabolic activity. During embryonic development, metabolically inactive yolk material is transformed into respiring tissues and thus, weight-specific respiration should theoretically increase during development. In $H$. araneus eggs, however, a more complicated pattern was observed (Fig. 7). High metabolic rates were measured at the beginning of embryogenesis, followed by an extended period with low metabolic activity in the gastrula stage (Phase II), another peak at the beginning of organ differentiation (Phase III), again a period of low metabolic activity (late Phase III), and a final increase, 1 or 2 months before hatching (Phase IV). This cyclic pattern indicates that the metabolic activity during embryogenesis of $\mathrm{H}$. araneus is not exclusively regulated by a changing ratio between metabolically inactive yolk material and respiring tissues. As another important factor, diapause-like resting periods may interrupt the developmental progress. This may cause the extremely long duration of embryogenesis observed in $H$. araneus (25).

Yolk is, during embryogenesis, the only energy source and the chemical substrate for tissue and organ differentiation. In $H$. araneus, proteins and lipids were found to be the main constituents of yolk. The degradation of lipids was, in $\mathrm{H}$. araneus, slightly higher $(69 \%)$ than in many other crustacean embryos, where normally $40 \%$ to $60 \%$ of the initial pool is utilized [e.g., $(14,1,27)]$. Within the lipid fraction, triacylglycerols and, to some extent, phospholipids also appear to represent the major fuel for embryonic development $(7,32)$. Unfortunately, no data are available on biochemical changes during the embryogenesis of other boreal spider crab species with a biennial reproductive cycle, namely Chionoecetes japonica (15) and C. opilio (30).

Relatively high depletion of lipids in $H$. araneus may be a consequence of its extremely long development duration, where resting periods are longer than in other brachyuran crabs (36). During such periods, utilization of storage material continues to maintain the basic metabolism, but without a developmental progress. Thus, the energetic costs of embryonic development are, on average, higher than in species with shorter or no resting periods. Periods of developmental arrest may coordinate the timing of hatching with the occurrence of sufficient food production in the plankton and thus, should be expected to have evolved in particular in high latitudes, where a pronounced seasonality of daylight and plankton production is a typical phenomenon $(19,25,33,36)$.

Carbohydrates are only a minor constituent of yolk in $H$. araneus, which represents a common trait in the eggs of marine crustaceans (14). During embryonic development, the carbohydrate content of the eggs increased slightly until hatching, probably due to gluconeogenesis. In spite of a small pool (normally remaining below $3 \%$ of DW), however, free carbohydrates may be an important intermediary product, with a high turnover rate, in the energy metabolism of the embryos. Their final decrease near hatching may be a consequence of chitin synthesis during cuticle formation.

There is much variation in the source of chemical energy during embryonic development in the Crustacea (Table 2). For larval decapods, it was suggested that bioenergetic traits might reflect phylogenetic trends (2). Within a taxonomic sequence (Caridea-Astacidea-Anomura-Brachyura), i.e., from plesiomorph toward increasingly apomorph groups (5), an increasing tendency in the average larval $\mathrm{C}: \mathrm{N}$ ratio and hence, in their lipid content was observed. This suggests an increasing significance of lipid reserves as a metabolic substrate in early ontogenetic stages, and thus, an increasing maternal energy investment per offspring, i.e., an evolutionary tendency from planktotrophy towards lecithotrophy. Since such tendencies must be reflected also in egg size and biochemistry (16), future studies should pay more attention 
TABLE 2. Comparison of relative lipid and protein depletion (in percent of total losses; carbohydrates and other fractions considered constant during embryogenesis (freshly laid eggs compared with freshly hatched larvae) in crustacean species with different taxonomic position habitat, initial egg weight, and initially available lipid and protein reserves (in percent of dry weight, DW)

\begin{tabular}{|c|c|c|c|c|c|c|c|}
\hline Species & Taxon & Habitat & $\begin{array}{c}\text { Initial DW } \\
(\mu \mathrm{g})\end{array}$ & $\begin{array}{c}\text { Initial lipid } \\
(\% \mathrm{DW})\end{array}$ & $\begin{array}{c}\text { Initial protein } \\
(\% \mathrm{DW})\end{array}$ & $\begin{array}{c}\text { Losses } \\
\text { lipid:protein }\end{array}$ & Reference \\
\hline Euphausia superba & Euphausiacea & Marine & 30 & 31.3 & 57.4 & $51: 49$ & (1) \\
\hline Crangon crangon & Caridea & Marine & 17 & 32.6 & 58.7 & $69: 31$ & $(22)$ \\
\hline Caridina weberi & Caridea & Freshwater & 22 & 44.3 & 51.9 & $30: 70$ & $(28)$ \\
\hline Macrobrachium idella & Caridea & Freshwater & 26 & 12.3 & 80.0 & $18: 82$ & (34) \\
\hline Macrobrachium rosenbergii & Caridea & Estuarine & 51 & 28.4 & 61.3 & $100: 0$ & $(7)$ \\
\hline Macrobrachium lamarrei & Caridea & Freshwater & 501 & 52.5 & 44.4 & $88: 12$ & $(17)$ \\
\hline Emerita holthuisi & Anomura & Freshwater & 8 & 12.6 & 80.6 & $12: 88$ & (35) \\
\hline Pagurus bernhardus & Anomura & Marine & 27 & 29.5 & 66.0 & $58: 42$ & (24) \\
\hline Homarus gammarus & Astacidea & Marine & 1700 & 43.8 & 47.4 & $80: 20$ & (23) \\
\hline Xantho bidentatus & Brachyura & Marine & 71 & 30.5 & 54.3 & $32: 68$ & (10) \\
\hline Hyas araneus & Brachyura & Marine & 69 & 30.6 & 33.9 & $66: 34$ & Present study \\
\hline
\end{tabular}

to the bioenergetic traits of embryonic development of decapod crustaceans.

This research was conducted as a part of the diploma thesis of the first author; supported by the Studienstiftung des deutschen Volkes, Bonn, Germany. We thank Prof. Dr. H. K. Schminke and Dr. J. Harms for their helpful suggestions, C. Püschel for carrying out CHN analyses, and $U$. Süsens and K. Riesebeck for occasional help in the maintenance of experimental animals.

\section{References}

1. Amsler, M.O.; George, R.Y. Changes in the biochemical composition of Euphausia superba Dana embryos during early development. Polar Biol. 4:61-63;1985.

2. Anger, K. Developmental changes in the bioenergetics of decapod larvae. Mem. Queensland 31:289-308;1991.

3. Anger, K.; Harms, J.; Püschel, C.; Seeger, B. Physiological and biochemical changes during the larval development of a brachyuran crab reared under constant conditions in the laboratory. Helgoländer Meeresunters. 43:225-244;1989.

4. Anger, K.; Harms, J.; Christiansen, M.E.; Süsens, U.; Wilmes, B. Growth patterns, chemical composition and oxygen consumption in early juvenile Hyas araneus (Decapoda: Majidae) reared in the laboratory. Helgoländer Meeresunters. 46:9-28; 1992.

5. Bowman, T.E.; Abele, L.G. Classification of the recent crustacea. In: Abele, L.G. (ed). The Biology of Crustacea, Vol. 1: Systematics, the Fossil Record, and Biogeography. New York: Academic Press; 1982:1-27.

6. Christiansen, M.E. Crustacea decapoda brachyura. Marine invertebrates of Scandinavia 2. Olso: Universitetsforlaget; 1969.

7. Clarke, A.; Brown, J.H.; Holmes, L.J. The biochemical composition of eggs from Macrobrachium rosenbergii in relation to embryonic development. Comp. Biochem. Physiol. 96B:505$511 ; 1990$.

8. Davis, C.C. A study of the hatching process in aquatic invertebrates. XIII. Events of eclosion in the American lobster, Homarus americanus Milne-Edwards (Astacura, Homaridae). Am. Midl. Natur. 72:203-210;1964.

9. DeVries, M.C.; Forward, R.B. Mechanisms of crustacean egg hatching: Evidence for enzyme release by crab embryos. Mar. Biol. 110:281-291;1991.
10. Erri Babu, D. Observations on the embryonic development and energy source in the crab Xantho bidentatus. Mar. Biol. 95: 123-127;1987.

11. Glas, P.S.; Green, J.D.; Lynn, J.W. Oxidase activity associated with the elevation of the penaeoid shrimp hatching envelope. Biol. Bull. 189:13-21;1995.

12. Green, J. Chemical embryology of crustacea. Cambridge Philos. Soc. Biol. Rev. 40:580-600;1965.

13. Grasshoff, K. Methods of Sea Water Analysis. Weinheim: Verlag Chemie; 1976.

14. Holland, D.L. Lipid reserves and energy metabolism in the larvae of benthic marine invertebrates. In: Malins, D.C.; Sargent, J.R. (eds). Biochemical and Biophysical Perspectives in Marine Biology. New York: Academic Press; 1978:85123.

15. Ito, K. Maturation and spawning of the queen crab, Chionoecetes japonica, in the Japan Sea, with special reference to the reproductive cycle. Bull. Jpn. Sea Reg. Fish. Res. Lab. 27: 59-74;1976.

16. Jaeckle, W.B. Variation in the size, energy content, and biochemical composition of invertebrate eggs: correlates to the mode of larval development. In: McEdward, L.R. (ed). Ecology of Marine Invertebrate Larvae. Boca Raton: CRC Press; 1995:49-77.

17. Katre, S. Yolk utilization in the freshwater prawn Macrobrachium lamarrei. J. Anim. Morphol. Physiol. 24:13-20;1977.

18. Köhler, W.; Schachtel, G.; Voleske, P. Biostatistik: Einführung in die biometrie für biologen und agrarwissenschaftler. Berlin, Heidelberg: Springer-Verlag; 1995.

19. Lovrich, G.A.; Vinuesa, J.H. Reproductive biology of the false southern king crab (Paralomis granulosa, Lithodidae) in the Beagle Channel, Argentina. Fish. Bull. 91:664-675;1993.

20. Lowry, O.H.; Rosebrough, N.J., Farr, A.L.; Randall, R.J. Protein measurement with the folin phenol reagent. J. Biol. Chem. 193:265-275;1951.

21. Needham, J. Biochemistry and Morphogenesis. Cambridge: Cambridge University Press; 1950.

22. Pandian, T.J. Changes in chemical composition and caloric content of developing eggs of the shrimp Crangon crangon. Helgoländer Wiss. Meeresunters. 16:216-224;1967.

23. Pandian, T.J. Ecophysiological studies on the developing eggs and embryos of the European lobster Homarus gammarus. Mar. Biol. 5:154-167;1970.

24. Pandian, T.J.; Schumann, K.-H. Chemical composition and 
caloric content of egg and zoea of the hermit crab Eupagurus bernhardus. Helgoländer Wiss. Meeresunters. 16:225-230; 1967.

25. Petersen, S. The embryonic development of Hyas araneus L. (Decapoda, Majidae): Effects of temperature. Sarsia 80:193$198 ; 1995$.

26. Quetin, L.B.; Ross, R.M. Depth distribution of developing Euphausia superba embryos, predicted from sinking rates. Mar. Biol. 79:47-53;1984.

27. Quetin, L.B.; Ross, R.M. Effects of oxygen, temperature and age on the metabolic rate of the embryos and early larval stages of the Antarctic krill Euphausia superba Dana. J. Exp. Mar. Biol. Ecol. 125:43-62;1989.

28. Rao, C.N.; Ponnuchamy, R.; Shakuntala, K.; Reddy, S.R. Fecundity and energetics of embryonic metabolism of Caridina weberi (De Man) (Decapoda: Atyidae). Int. J. Invertebrate Reprod. 3:75-85;1981.

29. Saigusa, M. Observations on egg hatching in the estuarine crab Sesarma haematocheir. Pacific Sci. 46:484-494;1992.

30. Sainte-Marie, B. Reproductive cycle and fecundity of primiparous and multiparous female Snow Crab, Chionoecetes opilio, in the northwest Gulf of Saint Lawrence. Can. J. Aquat. Sci. 50:2147-2156;1993.

31. Sasaki, G.C. Biochemical changes associated with embryonic and larval development in the American lobster Homarus americanus Milne Edwards. Dissertation. Woods Hole, MA: Woods Hole Oceanographic Institution, and Cambridge, MA: Massachusetts Institute of Technology; 1984.
32. Sasaki, G.C.; Capuzzo, J.M.; Biesiot, P. Nutritional and bioenergetic considerations in the development of the American lobster Homarus americanus. Can. J. Fish. Aquat. Sci. 43: 2311-2319;1986.

33. Shields, J.D.; Okazaki, R.K.; Kuris, A.M. Fecundity and the reproductive potential of the yellow rock crab Cancer anthonyi. Fish. Bull. 89:299-305;1991.

34. Vijayaraghavan, S.; Easterson, D.C.V. Biochemical changes and energy utilisation in developing stages of the estuarine prawn, Macrobrachium idella (Hilgendorf). J. Mar. Biol. Assoc. India 16:275-279;1974.

35. Vijayaraghavan, S.; Wafar, M.V.M.; Royen, J.P. Changes in the biochemical composition and energy utilisation in developmental stages of the mole crab Emerita holthuisi Sankolli. Mahasagar. Bull. Nat. Inst. Oceanogr. 8:165-170;1976.

36. Wear, R.G. Incubation in British decapod crustacea, and the effects of temperature on the rate and success of embryonic development. J. Mar. Biol. Assoc. UK 54:745-762;1974.

37. Winberg, G.G. Methods for the Estimation of Production of Aquatic Animals. London: Academic Press; 1971.

38. Zöllner, N.; Kirsch, K. Über die quantitative Bestimmung von Lipoiden (Mikromethode) mittles der vielen natürlichen Lipoiden (allen bekannten Plasmalipoiden) gemeinsamen Sulfophosphovanillin-Reaktion. Z. Ges. Exp. Med. 135:545-561; 1962. 